\title{
EFEKTIVITAS TEKNIK REPEATED ORAL READING DAN IMPLEMENTASI TEKNIK-TEKNIK MODIFIKASI PERILAKU DALAM MENINGKATKAN KELANCARAN MEMBACA PADA ANAK DENGAN MILD INTELLECTUAL DISABILITY
}

\author{
Farraas Afiefah Muhdiar dan Eko Handayani \\ Fakultas Psikologi, Universitas Indonesia \\ Lingkar Kampus Raya Mawar 53 8, Pondok Cina, Beji, Jawa Barat 16424 \\ Email: farraasmuhdiar@gmail.com
}

Diserahkan 23 April 2019; Diterima 19 Juli 2019; Dipublikasikan 01 Agustus 2019

\begin{abstract}
ABSTRAK
Penelitian ini dilakukan untuk menguji efektivitas teknik repeated reading dan implementasi teknik prompt, reinforcement, serta positive practice dalam meningkatkan kelancaran membaca pada anak dengan mild intellectual disability. Penelitian single case study ini dilakukan dalam 20 sesi dengan changing criterion design. Partisipan dalam penelitian ini adalah anak laki-laki berusia 12 tahun dengan mild intellectual disability yang belum dapat membaca dengan lancar, meskipun sudah mampu mengeja. Hasil penelitian menunjukkan bahwa teknik repeated reading dan implementasi teknik-teknik modifikasi perilaku dapat meningkatkan kelancaran membaca pada anak dengan mild intellectual disability dengan efektif.
\end{abstract}

Kata kunci: intellectual disability; membaca; intervensi; modifikasi perilaku

\section{THE EFFECTIVENESS OF REPEATED ORAL READING AND BEHAVIORAL MODIFICATION TECHNIQUES TO IMPROVE READING FLUENCY IN CHILDREN WITH MILD INTELLECTUAL DISABILITY}

\begin{abstract}
This study was conducted to examine the effectiveness of repeated reading techniques and the implementation of prompt, reinforcement, and positive practice techniques in improving reading fluency in children with mild intellectual disability. This single case study was conducted in 20 sessions with changing criterion design. The participant was 12-year-old boys with mild intellectual disability who could not read fluently, although he was able to spell. The results showed that the repeated reading technique and implementation of behavior modification techniques could improve reading fluency in children with mild intellectual disability effectively.
\end{abstract}

Keywords: intellectual disability; reading; intervention; behavior modification.

\section{PENDAHULUAN}

Di dalam DSM-5 (APA, 2013), intellectual disability (ID) dijelaskan sebagai gangguan yang muncul pada usia perkembangan, yang meliputi keterbatasan pada aspek intelektual dan fungsi adaptif pada domain konseptual, sosial, dan kehidupan sehari-hari. Keterbatasan kemampuan kognitif yang dimiliki oleh anak-anak dengan intellectual disability, seperti dalam hal kapasitas working memory serta kemampuan bahasa, menghambat perkembangan membaca mereka (van
Wingerden, Segers, van Balkom, \& Verhoeven, 2017). Keterbatasan keterampilan membaca pada anak dengan intellectual disability ini kerap mengganggu efektivitas pembelajaran anak, karena keterampilan membaca adalah salah satu prasyarat utama bagi keberhasilan akademik seorang siswa (Alnahdi, 2015).

Menurut Pertiwi (2016), tahapan membaca di dalam Bahasa Indonesia diawali dengan (1) kemampuan mengucapkan bunyi huruf vokal; (2) kemampuan mengucapkan bunyi huruf konsonan; (3) kemampuan mengeja 1 huruf konsonan dan 1 huruf vokal; (4) kemampuan mengeja suku kata 
terbuka (vokal-konsonan-vokal; seperti "ibu"); (5) kemampuan mengeja suku kata terbuka (konsonanvokal-konsonan-vokal) yang sama (seperti "susu"); (6) kemampuan mengeja suku kata terbuka (konsonan-vokal-konsonan-vokal) yang berbeda (seperti "baju"); (7) kemampuan mengeja suku kata tertutup (konsonan-vokal-konsonan-vokal-konsonan; seperti "bagus"); (8) kemampuan mengeja suku kata yang mengandung vokal berganding (seperti "au" pada kata "pisau" dan "harimau"); dan (9) kemampuan mengeja suku kata yang mengandung konsonan berganding (seperti "ng" pada kata "singa" dan "payung" dan "ny" pada kata "senyum").

Proses membaca membutuhkan dua tugas kognitif: (1) decoding, pengenalan terhadap tulisan dan (2) comprehension, yaitu pemahaman terhadap makna dari kata yang telah dibaca (National Reading Panel, 2000). Decoding dan comprehension membutuhkan sumber daya kognitif yang jumlahnya cukup terbatas karena keterbatasan daya ingat yang dimiliki manusia. Pada anak yang belum dapat membaca dengan lancar, semua sumber daya kognitif yang tersedia tersalurkan untuk menyelesaikan tugas decoding, sehingga tidak ada lagi sumber daya untuk melakukan tugas comprehension. Anak yang belum dapat membaca dengan lancar biasanya kesulitan untuk memahami makna dari teks yang dibaca karena mereka memfokuskan diri untuk memproses huruf-huruf yang dibaca menjadi sebuah kata, bukan untuk memahami makna yang disampaikan oleh tulisan tersebut. Sebaliknya, anak yang telah mampu membaca dengan lancar mampu menyelesaikan tugas decoding dan comprehension pada saat yang bersamaan. Karenanya, beberapa penelitian menemukan bahwa kelancaran membaca merupakan salah satu indikator utama dari keterampilan membaca seseorang dan prediktor terbaik dari kemampuan seseorang dalam memahami bacaan (Hudson, Lane, \& Pullen, 2005; Pikulski \& Chard, 2005). Anak yang belum dapat membaca dengan lancar akan kesulitan untuk memahami apa yang ia baca, sehingga juga akan mengalami kesulitan untuk mempelajari sesuatu dari bahan bacaan secara mandiri. Adapun kelancaran membaca didefinisikan oleh Hudson et al. (2005) sebagai keterampilan untuk membaca naskah dengan akurat, dengan kecepatan yang sesuai dengan tingkat percakapan, dan dengan ekspresi atau intonasi (prosody) yang tepat.
Penelitian yang dilakukan terhadap jutaan siswa di Amerika menemukan bahwa rata-rata kecepatan membaca secara nyaring (oral reading fluency) di dalam konteks sebanyak 60 kata benar per menit (KBPM) untuk siswa kelas 1 sekolah dasar, 100 KBPM untuk siswa kelas 2, 112 KBPM untuk siswa kelas 3, 133 WPM untuk siswa kelas 4, 146 untuk siswa kelas 5, dan 146 untuk siswa kelas 6 (Hasbrouck \& Tindal, 2017). Sayangnya, belum terdapat data serupa untuk anak-anak di Indonesia.

Berdasarkan pemaparan di atas, dapat dilihat bahwa intervensi untuk meningkatkan kelancaran membaca diperlukan bagi anak-anak yang kelancaran membacanya masih jauh di bawah ratarata, karena kelancaran membaca sangat berpengaruh terhadap kemampuan seseorang dalam memahami bacaan. Intervensi dalam penelitian ini akan dilakukan dengan menggunakan teknik repeated oral reading procedures, yakni pendekatan membaca secara nyaring dengan bantuan orang dewasa yang dilakukan secara berulang; yang teah teruji efektif untuk meningkatkan kelancaran membaca (National Reading Panel, 2000). Agar lebih efektif, intervensi juga sebaiknya melibatkan direct corrective feedback, yakni koreksi terhadap kesalahan pengucapan atau tulisan yang terlewat (omission) ketika murid membaca atau setelah mereka selesai membaca, baik dengan diberikan contoh secara langsung maupun diberikan prompt untuk mengulang kembali kata yang kurang tepat tersebut (Therrien, 2004). Selain repeated oral reading dan direct corrective feedback, teknik modifikasi perilaku seperti positive reinforcement dan positive practice juga akan diterapkan untuk meningkatkan efektivitas intervensi.

Di dalam penelitian ini, corrective feedback diberikan dalam bentuk prompts, yakni antecedent stimulus tambahan untuk meningkatkan presentasi kemunculan perilaku yang diharapkan (Martin \& Pear, 2015). Kemunculan prompt dikurangi secara bertahap (fading) pada setiap sesi, mulai dari modeling (mencontohkan langsung dan meminta anak menirunya), verbal prompt (mengarahkan anak melalui instruksi verbal), serta visual prompt (mengarahkan anak melalui instruksi yang ditampilkan secara visual).

Selain itu, teknik positive reinforcement, yakni sebuah kejadian yang dapat meningkatkan kemunculan respons ketika ditampilkan setelah kemunculan respons tersebut (Martin \& Pear, 2015) 
juga digunakan di dalam penelitian ini. Terdapat dua jenis reinforcers yang digunakan di dalam penelitian ini, yaitu contingent dan non-contingent reinforcers. Contingent reinforcers adalah reinforcers yang diberikan setelah kemunculan perilaku tertentu, yang dapat meningkatkan kualitas dari perilaku yang sedang dilatihkan (Martin \& Pear, 2015). Contingent reinforcers berupa consumable dan activity reinforcers diberikan dalam bentuk token, yakni conditioned reinforcers yang dapat diakumulasikan dan ditukar untuk mendapatkan backup reinforcers (Martin \& Pear, 2015). Penggunaan token economy ditemukan sangat efektif untuk meningkatkan prestasi akademis pada remaja dengan intellectual disability; bahkan melebihi social reinforcement (Mirzamani, Ashoori, \& Sereshki, 2011). Sementara itu, non-contingent reinforcers diberikan pada setiap sesi untuk meningkatkan motivasi belajar partisipan. Partisipan mendapatkan reinforcers atas partisipasinya, meskipun belum mampu memenuhi target perilaku yang telah ditetapkan.

Intervensi ini juga menerapkan teknik positive practice jika anak melakukan kesalahan saat membaca. Positive practice adalah teknik modifikasi perilaku yang dilakukan dengan meminta individu mempraktikkan perilaku yang diharapkan muncul secara berulang, segera setelah individu tersebut melakukan perilaku yang tidak tepat (Carey \& Bucher, 1983). Penerapan teknik tersebut terbukti efektif dalam mengurangi kesalahan membaca pada anak dengan gangguan intelektual (Singh, Singh, \& Winton, 1984).

Berdasarkan penelitian meta-analisis yang dilakukan oleh Therrien (2004), intervensi membaca ditemukan memiliki dampak yang jauh lebih kuat jika anak diminta untuk membaca hingga mencapai kriteria kecepatan dan ketepatan tertentu; bukan membaca naskah sejumlah frekuensi yang telah ditetapkan sebelumnya. Oleh karena itu, dalam intervensi ini, partisipan harus melewati target-target tertentu sebelum berpindah ke target-target di subfase berikutnya.

Intervensi diberikan dengan menggunakan dua buah stimulus bacaan: Daftar kata yang belum mampu dibaca partisipan dengan lancar serta teks bacaan yang melibatkan beberapa kata tersebut. Kedua tugas membaca tersebut membutuhkan proses kognitif yang berbeda (Jenkins, Fuchs, van den Broek, Espin, \& Deno, 2003). Membaca daftar kata, yang disebut juga dengan reading in isolation atau context-free reading, menginisiasi pemrosesan semantik (pengaitan tulisan dengan makna), sedangkan membaca tulisan di dalam bentuk kalimat, yang disebut juga dengan reading in context, lebih membutuhkan pemprosesan perseptual (Martin-Chang \& Levesque, 2013). Menurut Jenkins et al., anak dengan masalah membaca biasanya lebih mampu membaca kata di dalam bentuk kalimat, karena mereka dapat menggunakan strategi menebak kata untuk mengompensasi kemampuan identifikasi kata yang kurang baik. Kata-kata yang digunakan di dalam intervensi ini diambil dari naskah bacaan yang terdapat di buku pelajaran kelas 1 hingga $3 \mathrm{SD}$, sesuai dengan kapasitas intelektual partisipan.

\section{METODE}

\section{Desain Penelitian}

Penelitian ini dilakukan melalui changingcriterion design, yakni desain penelitian yang melibatkan satu partisipan (single-subject research) di mana perilaku individu dibentuk dengan meningkatkan kriteria keberhasilan dan derajat kesukaran tugas selama periode intervensi (James, 2016). Penelitian ini juga menggunakan desain penelitian A-B-A atau reversal design, yang melibatkan pengambilan data baseline, intervensi, dan baseline kembali (tanpa intervensi).

\section{Partisipan}

Partisipan dalam penelitian ini adalah $\mathrm{S}$, seorang anak laki-laki berusia 12 tahun yang duduk di kelas 1 SMP Negeri di Jakarta. S memiliki taraf kecerdasan yang berfungsi jauh di bawah rata-rata anak seusianya ( $\mathrm{IQ}=53$, skala WISC-R). S juga menunjukkan keterbatasan pada keterampilan adaptif dalam taraf ringan, khususnya pada ranah sosial dan konseptual. Berdasarkan karakteristik IQ dan kemampuan adaptifnya, menurut DSM 5 (American Psychiatric Association, 2013), S digolongkan ke dalam kelompok anak dengan mild intellectual disability.

Meskipun telah duduk di bangku kelas 1 SMP Negeri (inklusi), keterampilan membaca $S$ saat ini setara dengan siswa kelas 1-2 SD. S sudah mampu membaca dan mengeja kata terbuka maupun tertutup, tetapi masih terbata-bata dalam membaca kata-kata dengan lebih dari 3 suku kata dan mengandung konsonan yang berganding (contohnya kata yang mengandung "ng", "br", atau "ny") atau 
vokal yang berganding (contohnya "au", "ai", atau "aa"). Secara umum, S hanya dapat membaca sekitar 20-52 kata di dalam bentuk cerita (bacaan di dalam konteks) selama satu menit. $\mathrm{S}$ juga masih membutuhkan bantuan untuk memahami bacaan yang terdiri dari beberapa paragraf dan memuat katakata yang abstrak. Hal ini membuatnya belum mampu mengerjakan soal ujian secara mandiri, sehingga menghambatnya dalam kegiatan akademis di sekolah. Karena kelancaran membaca yang terbatas, $\mathrm{S}$ juga memiliki kesulitan untuk memahami informasi-informasi yang tersedia di sekitarnya dalam bentuk tulisan.

\section{Teknik Intervensi}

Berikut adalah penjelasan dari penggunakan teknik-teknik behavioral modification di dalam intervensi ini:

\section{(1) Positive reinforcement}

Berikut adalah jenis reinforcement yang diberikan beserta penjadwalannya:

\section{i. $\quad$ Social Reinforcers}

Social reinforcers berupa pujian dan gestur diberikan ketika partisipan berhasil membaca setiap halaman tulisan berisi daftar kata maupun naskah bacaan. Peneliti juga memberikan pujian ketika partisipan berhasil menunjukkan performa membaca yang lebih baik daripada percobaan sebelumnya.

\section{ii. $\quad$ Consumable dan Activity Reinforcers}

Consumable dan Activity Reinforcers diberikan dalam bentuk token system. Partisipan mendapatkan satu bintang untuk setiap naskah bacaan atau satu halaman daftar kata yang berhasil dibaca dengan kelancaran yang lebih baik daripada percobaan sebelumnya. Jika berhasil memperoleh lima belas bintang, $\mathrm{S}$ memperoleh reinforcement tambahan berupa makanan ringan atau minuman dalam kemasan. Jika berhasil memperoleh 60 bintang, S memperoleh reinforcement berupa pergi ke lokasi yang diinginkan bersama keluarganya.

Sementara itu, activity reinforcers berupa aktivitas menonton televisi dan memainkan telepon genggam akan diberikan secara non-contingent. Setiap berhasil menyelesaikan dua set bacaan (dua halaman daftar kata dan dua naskah bacaan), partisipan mendapatkan waktu 10 menit untuk beristirahat, yang dapat ia gunakan untuk menonton televisi atau memainkan telepon genggam.

\section{(2) Prompts (Corrective Feedback)}

Corrective feedback dalam bentuk verbal akan diberikan pada percobaan pertama dan kedua di setiap sesi. Setiap $\mathrm{S}$ melakukan kesalahan saat membaca naskah bacaan yang baru untuk pertama kalinya, pemeriksa memberikan verbal prompts, misalnya dengan berkata "ulangi" atau "hmm....". Hal yang sama dilakukan pemeriksa ketika $S$ tetap belum dapat membaca kata tersebut dengan tepat. Jika tetap salah, pemeriksa membacakan kata yang tepat dan meminta $\mathrm{S}$ untuk mengulanginya (modeling). Setelah mengulangi kata yang salah hingga tepat, $\mathrm{S}$ akan diminta untuk mengulangi kalimat tersebut hingga tepat.

Pada percobaan ketiga di setiap sesi, corrective feedback diberikan dalam bentuk tulisan. Pemeriksa melingkari kata yang salah dan meminta anak untuk mengulang kembali kata-kata tersebut setelah seluruh naskah berhasil dibaca hingga selesai.

\section{Positive Practice}

Teknik positive practice diterapkan pada percobaan pertama dan kedua di setiap sesi dengan meminta anak mengulang membaca kata setiap kali ia melakukan kesalahan membaca hingga mampu menyebutkan kata yang tepat. Dalam naskah bacaan, anak diminta untuk mengulang satu kalimat secara utuh meskipun ia hanya melakukan kesalahan membaca pada satu kata atau tidak memberikan jeda saat menemui tanda baca. Anak diminta mengulangi membaca beberapa kali, hingga mampu membaca kalimat tersebut dengan tepat.

Untuk lebih jelasnya, berikut adalah penjelasan detail dari setiap percobaan yang dilakukan pada setiap sesi intervensi:

Tabel 3. Penerapan Teknik Prompts dan Positive Practice pada Sesi Intervensi

\begin{tabular}{clll}
\hline $\begin{array}{c}\text { Per- } \\
\text { coba } \\
\text {-an }\end{array}$ & $\begin{array}{c}\text { Prompts / } \\
\text { Corrective } \\
\text { Feedback dan } \\
\text { Positive Practice }\end{array}$ & $\begin{array}{c}\text { Positive } \\
\text { Reinfor- } \\
\text { cers } \\
\text { (Token) }\end{array}$ & $\begin{array}{c}\text { Kete- } \\
\text { rangan }\end{array}$ \\
\hline \multirow{2}{*}{1} & Corrective feedback & 1 stiker & Performa \\
& secara verbal & jika & anak tidak \\
& diberikan segera & berhasil & dicatat \\
\hline
\end{tabular}




\begin{tabular}{|c|c|c|c|}
\hline 2 & $\begin{array}{l}\text { setelah partisipan } \\
\text { melakukan } \\
\text { kesalahan. Anak } \\
\text { diminta mengulangi } \\
\text { membaca } \\
\text { kata/kalimat yang } \\
\text { salah hingga tepat } \\
\text { (positive practice). }\end{array}$ & $\begin{array}{l}\text { memenuhi } \\
\text { target } \\
\text { akurasi } \\
\text { dan } \\
\text { intonasi. }\end{array}$ & $\begin{array}{l}\text { sebagai } \\
\text { data } \\
\text { dalam } \\
\text { penelitian. }\end{array}$ \\
\hline 3 & $\begin{array}{l}\text { Corrective feedback } \\
\text { melalui tanda } \\
\text { tertulis diberikan } \\
\text { setelah partisipan } \\
\text { membaca seluruh } \\
\text { teks. }\end{array}$ & \multirow{2}{*}{$\begin{array}{l}1 \text { stiker } \\
\text { jika } \\
\text { berhasil } \\
\text { memenuhi } \\
\text { target } \\
\text { kecepatan, } \\
\text { akurasi, } \\
\text { dan } \\
\text { intonasi. }\end{array}$} & \\
\hline 4 & Tidak ada feedback. & & $\begin{array}{l}\text { Performa } \\
\text { anak } \\
\text { dicatat } \\
\text { sebagai } \\
\text { data } \\
\text { penelitian. }\end{array}$ \\
\hline
\end{tabular}

\section{Alat dan Bahan}

Peneliti menggunakan dua jenis bahan bacaan: naskah bacaan untuk melatih keterampilan membaca di dalam konteks serta daftar kata untuk melatih keterampilan membaca di luar konteks. Daftar kata diperoleh secara acak dari kata-kata yang digunakan pada buku pelajaran kelas 1-3 SD, yang terdiri dari kata terbuka tanpa huruf konsonan dan vokal berganding, kata tertutup tanpa huruf konsonan dan vokal berganding, serta kata dengan huruf konsonan dan vokal berganding; yang terdiri dari 3-10 huruf dan 2-5 suku kata. Kata disusun berdasarkan tingkat kesulitan, yang ditentukan dari jenis kata dan jumlah suku kata. Sementara itu, naskah bacaan yang digunakan adalah naskah bacaan yang terdiri dari 80100 kata yang diperoleh dari buku pelajaran kelas 1 hingga 3 SD yang diterbitkan secara elektronik oleh Kementerian Pendidikan dan Kebudayaan RI.

Selain itu, alat dan bahan yang juga digunakan adalah stiker serta selembar tabel kosong untuk meletakkan stiker yang telah diperoleh sebagai token, alat pencatat waktu, serta alat tulis.

\section{Variabel Penelitian}

Variabel dalam penelitian ini adalah kelancaran membaca, yang diukur melalui tiga aspek: kecepatan membaca, akurasi membaca, serta ketepatan ekspresi atau intonasi (Hudson et al., 2005). Kecepatan membaca diukur melalui jumlah kata benar per menit (KBPM). Sebuah kata dianggap dibaca dengan benar jika partisipan membacanya dengan benar dan secara mandiri. Sebuah kata tetap dianggap dibaca benar jika partisipan melakukan kesalahan dalam membacanya, tetapi memperbaikinya sendiri dalam waktu tiga detik. Akurasi membaca diukur melalui persentase kata yang berhasil dibaca dengan benar. Sebuah kata dianggap salah jika partisipan salah membaca kata tersebut, melafalkannya dengan tidak tepat, ataupun melewati kata tersebut. Sementara itu, intonasi membaca diukur melalui persentase jumlah hentian pada kata sebelum tanda baca koma, titik, tanda tanya, dan tanda seru.

\section{Prosedur}

\section{Baseline}

Sebelum melakukan intervensi, peneliti melakukan pengukuran kecepatan, akurasi, serta akurasi intonasi membaca $\mathrm{S}$ sebagai data baseline. Selama pengukuran, peneliti memberikan instruksi kepada $\mathrm{S}$ untuk membaca daftar kata (membaca di luar konteks) serta naskah bacaan (membaca di dalam konteks) tanpa memberikan feedback apa pun. Kecepatan membaca dan akurasi membaca diukur dengan kedua stimulus tersebut, sedangkan intonasi membaca hanya diukur dari stimulus naskah bacaan. Pengukuran baseline dilakukan dalam tiga sesi pada tiga hari yang berbeda, dengan jarak pengambilan data dua hari, untuk melihat konsistensi dari kelancaran membaca S. Untuk memastikan kondusivitas dari kondisi ruangan, pengambilan baseline dilakukan di ruangan tertutup di rumah $\mathrm{S}$, tanpa kehadiran orang lain selain $\mathrm{S}$ dan peneliti. Hasil baseline digunakan untuk menentukan target kecepatan, akurasi, dan ketepatan intonasi pada intervensi yang dilakukan.

\section{Intervensi}

Intervensi diberikan oleh peneliti selama 15 sesi dengan frekuensi 5 kali seminggu. Setiap sesi intervensi berlangsung selama sekitar 60 menit. Jumlah sesi dan durasi intervensi disesuaikan dengan kemampuan S dalam memenuhi target-target pada kelima subfase di atas. Dalam sesi intervensi, partisipan diminta untuk membaca daftar kata dan satu buah naskah (setara dengan bacaan untuk siswa kelas 1 hingga 3 SD) selama beberapa kali hingga mencapai target kelancaran membaca yang telah ditetapkan.

Intervensi dilakukan dengan menggunakan changing-criterion designs, dengan target membaca di luar konteks (dengan daftar kata) untuk setiap subfase seperti pada Tabel 1. 
Tabel 1. Target Membaca di Luar Konteks Per Sesi

\begin{tabular}{cccc}
\hline \multicolumn{4}{c}{ Membaca di Luar Konteks } \\
\hline $\begin{array}{c}\text { Sub } \\
\text { fase }\end{array}$ & Level Stimulus & Target & $\begin{array}{c}\text { Target } \\
\text { (sesi ke-) }\end{array}$ \\
\hline 1 & $\begin{array}{c}\text { Tanpa huruf vokal \& } \\
\text { konsonan berganding }\end{array}$ & $\begin{array}{c}25 \mathrm{KBPM}, \\
\text { akurasi 80\% }\end{array}$ & 4 \\
\hline 2 & $\begin{array}{c}\text { Dengan huruf vokal \& } \\
\text { konsonan berganding }\end{array}$ & $\begin{array}{c}20 \mathrm{KBPM}, \\
\text { akurasi 80\% }\end{array}$ & 6 \\
\hline 3 & $\begin{array}{c}\text { Dengan huruf vokal \& } \\
\text { konsonan berganding }\end{array}$ & $\begin{array}{c}25 \mathrm{KBPM}, \\
\text { akurasi 85\% }\end{array}$ & 9 \\
\hline 4 & Campuran & $\begin{array}{c}30 \mathrm{KBPM}, \\
\text { akurasi 90\% }\end{array}$ & 12 \\
\hline 5 & Campuran & $\begin{array}{c}32 \mathrm{KBPM}, \\
\text { akurasi 95\% }\end{array}$ & 15 \\
\hline 6 & Campuran & $\begin{array}{c}35 \mathrm{KBPM}, \\
\text { Akurasi 98\% }\end{array}$ & 18 \\
\hline
\end{tabular}

Sementara itu, target membaca di dalam konteks (dengan naskah bacaan) pada intervensi ini dapat dilihat pada tabel 2.

Tabel 2. Target Membaca di Dalam Konteks Per Sesi

\begin{tabular}{cccc}
\hline $\begin{array}{c}\text { Sub } \\
\text { fase }\end{array}$ & Level Stimulus & Target & Target \\
(sesi ke-)
\end{tabular}

\section{Follow-Up}

Follow-up dilakukan untuk mengetahui sejauh mana kemajuan yang terjadi setelah intervensi dapat bertahan. Follow up dilakukan selama dua sesi (sesi ke-19 dan 20), pada dua minggu dan satu bulan setelah intervensi selesai dilakukan. Pada sesi follow up, pemeriksa melakukan pengukuran kembali pada target perilaku tanpa diberikan intervensi terlebih dahulu.

\section{HASIL DAN PEMBAHASAN}

Berdasarkan Gambar 1 dan Gambar 2, dapat dilihat bahwa semua aspek kelancaran membaca mengalami peningkatan selama intervensi. Peningkatan yang paling signifikan terlihat dari ketepatan membaca intonasi. Sebelum intervensi dimulai, S mampu membaca 82 hingga 89 persen tanda baca (titik dan koma) dengan tepat. Jumlah ini meningkat dengan konsisten; ia mampu mempertahankan untuk membaca tanda baca dengan sangat tepat $(100 \%)$ sejak sesi intervensi kesepuluh hingga akhir intervensi.

\section{Gambar 1. Grafik Membaca di Dalam Konteks (Naskah Bacaan)}

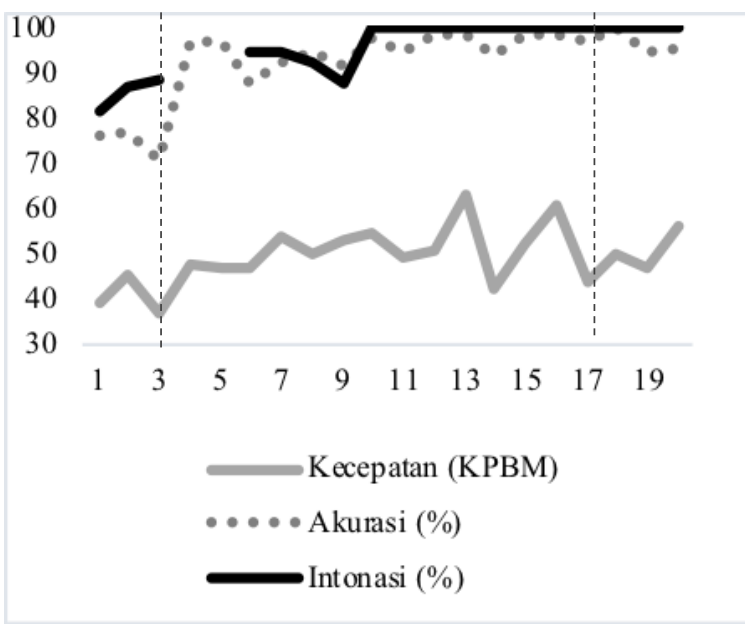

Gambar 2. Grafik Membaca di Luar Konteks (Daftar Kata)

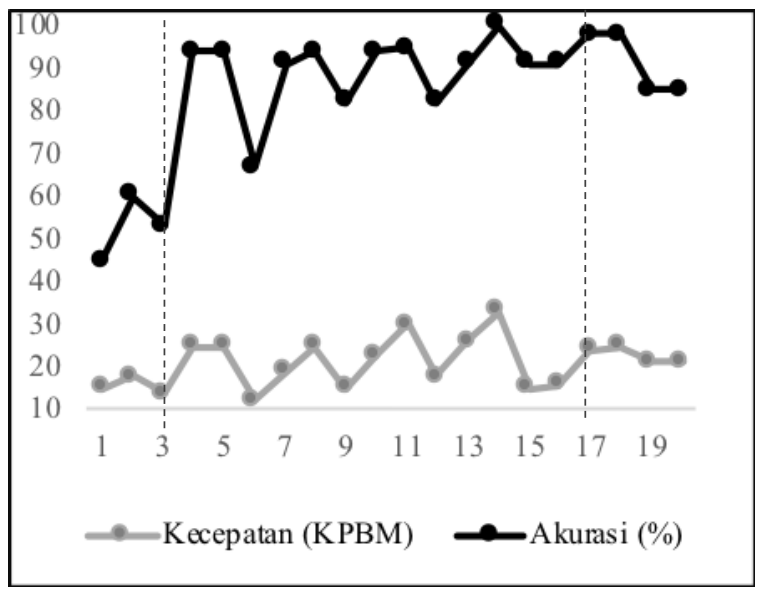


Akurasi S dalam membaca juga mengalami peningkatan yang signifikan. Awalnya, S mampu membaca $71-77 \%$ kata dalam naskah bacaan serta 45-60\% kata dalam daftar kata dengan tepat. Sepanjang intervensi, akurasi ini meningkat dengan tajam, hingga mencapai $100 \%$.

Data menunjukkan bahwa peningkatan akurasi selama intervensi lebih pesat dan konsisten jika dibandingkan dengan peningkatan kecepatan membaca. Sementara itu, pada sesi baseline, S hanya mampu membaca naskah (membaca di dalam konteks) 37 hingga 45 kata per menit serta 14 hingga 18 kata per menit untuk daftar kata (membaca di luar konteks). Kecepatan baca $\mathrm{S}$ cenderung meningkat sepanjang intervensi, hingga mencapai 63 kata per menit untuk membaca di dalam konteks dan 33 kata per menit untuk membaca di luar konteks.

Peningkatan keterampilan membaca seperti yang telah dijelaskan di atas bertahan hingga setelah intervensi selesai dilakukan. Satu bulan setelah intervensi berakhir, $S$ masih mampu membaca naskah dengan kecepatan 56 kata per menit, akurasi $96 \%$, dan akurasi intonasi $100 \%$. Untuk daftar kata, $\mathrm{S}$ mampu membacanya dengan kecepatan 21 kata per menit dengan akurasi $85 \%$. Meskipun sedikit mengalami penurunan jika dibandingkan dengan sesi intervensi, kelancaran membaca $\mathrm{S}$ setelah intervensi berakhir tetap jauh lebih baik daripada sebelum intervensi diberikan.

Selama intervensi, $\mathrm{S}$ sudah mampu meningkatkan keterampilannya dalam membaca kata-kata yang melibatkan huruf konsonan berganding; yang awalnya sulit dilakukan. Ia juga sempat menunjukkan kesulitan untuk membaca kata yang diawali dengan huruf konsonan berganding (misalnya "nyata", "Bromo", dan "drama". Akan tetapi, setelah beberapa sesi, S akhirnya mampu membaca kata-kata tersebut dan kata-kata baru yang memuat kesulitan sejenis. Ia juga beberapa kali melakukan koreksi secara mandiri (self-correction) ketika membaca.

Meskipun menunjukkan kemajuan dalam membaca kata-kata yang rumit, hingga akhir intervensi, ia masih tetap melakukan beberapa kesalahan secara berulang, misalnya membaca suku kata berakhiran "n" dengan "ng" (misalnya "ulun" menjadi "ulung"), tertukar saat membaca kata berimbuhan "pe-“" dan "me-" (misalnya membaca "pengunjung" dengan "mengunjung"), melewatkan suku kata yang berulang (misalnya membaca "beberapa" dengan "berapa"), serta melewatkan salah satu huruf vokal berganding yang berada di tengah kata (misalnya tidak membaca huruf B dalam menyebrangi atau huruf $\mathrm{n}$ dalam membangun).

Selain hasil di atas, orangtua $S$ juga melaporkan adanya peningkatan motivasi membaca di luar sesi intervensi. Menurut ibu, selama intervensi berlangsung, $\mathrm{S}$ menunjukkan daya tahan yang lebih baik dalam membaca. Sebelum intervensi berjalan, $\mathrm{S}$ seringkali mengeluh saat diminta ibu untuk membaca 1 halaman naskah bacaan. Akan tetapi, selama intervensi berlangsung, $\mathrm{S}$ membaca 1 halaman atau lebih tanpa mengeluh. Selain itu, menurut pengamatan ibu, $S$ juga menjadi jauh lebih hati-hati saat menemukan tanda baca titik atau koma. Ibu memaparkan bahwa sejak intervensi dimulai, bacaan $\mathrm{S}$ menjadi lebih dipahami, karena ia lebih memperhatikan intonasi dan tanda baca. Padahal, sebelum intervensi dimulai, ibu juga sudah sering mengingatkan $\mathrm{S}$ untuk memperhatikan tanda baca titik.

Secara umum, hasil penelitian menunjukkan bahwa teknik repeated oral readings yang dikombinasikan dengan teknik-teknik modifikasi perilaku seperti prompts, reinforcement, dan positive practice efektif dalam meningkatkan keterampilan membaca $\mathrm{S}$

Hasil tersebut dapat dijelaskan melalui beberapa hal. Pertama, pengulangan saat membaca kemungkinan menyebabkan anak mampu mengingat kata dengan lebih baik. Penelitian yang dilakukan oleh Horst, Parsons, dan Bryan (2011) menemukan bahwa membaca cerita secara berulang lebih efektif dalam membantu anak mengingat kata baru daripada membaca banyak bahan bacaan yang berbeda.

Penggunaan daftar kata untuk melatih keterampilan membaca di luar konteks yang disesuaikan dengan tingkat keterampilan membaca anak saat ini dapat membantu anak menguasai katakata yang menantang untuknya. Dengan ditampilkan secara berulang, anak mendapatkan banyak kesempatan untuk berlatih membaca kata-kata tersebut. Sementara itu, naskah bacaan lebih efektif digunakan untuk meningkatkan kecepatan membaca dan ketepatan intonasi dalam membaca. Akan tetapi, peningkatan akurasi lebih tepat dilakukan dengan naskah dalam bentuk daftar kata, berisi kata-kata yang masih kesulitan dibaca oleh S. Karena perbedaan ini, peneliti menyimpulkan bahwa kedua jenis bacaan sebaiknya digunakan sebagai media 
belajar bagi peserta didik yang sedang belajar membaca atau ingin meningkatkan kelancaran membacanya.

Data menunjukkan bahwa peningkatan akurasi selama intervensi lebih pesat dan konsisten jika dibandingkan dengan peningkatan kecepatan membaca. Hal ini mungkin berhubungan dengan penggunaan Bahasa Indonesia yang memiliki shallow ortography, di mana fonem dan grafemnya memiliki hubungan yang pasti (misanlya huruf a selalu dibaca dengan "a"). Penelitian menunjukkan bahwa anak yang mengalami gangguan membaca pada bahasa dengan shallow ortography biasanya menunjukkan kelemahan yang signifikan pada kecepatan membaca jika dibandingkan dengan anakanak seusianya; bukan pada akurasi membaca seperti yang ditemukan pada anak-anak yang kesulitan membaca tulisan dengan deep orthography seperti Bahasa Inggris (Serrano \& Defior, 2008). Meskipun membutuhkan waktu yang lebih lama untuk ditingkatkan, hasil penelitian ini menunjukkan bahwa latihan membaca yang melibatkan pengulangan dan penerapan teknik-teknik modifikasi perilaku dapat meningkatkan kecepatan membaca.

Grafik kelancaran membaca yang fluktuatif menunjukkan bahwa performa $\mathrm{S}$ dalam membaca sering kali berubah selama intervensi berlangsung, meskipun secara umum tetap menunjukkan peningkatan. Berdasarkan observasi dan wawancara yang dilakukan oleh peneliti, umumnya kelancaran membaca $S$ mengalami penurunan yang cukup signifikan (misalnya pada sesi ke-6, 12, dan 15) ketika kualitas tidurnya tidak baik pada malam sebelumnya atau ketika suasana hati $\mathrm{S}$ sedang tidak baik; misalnya jika sebelum intervensi dilakukan ia dimarahi ayah atau dilarang menonton televisi oleh ibu. Artinya, kerja sama dengan keluarga sangat diperlukan untuk mengoptimalisasi manfaat dari sebuah intervensi.

Meskipun berhasil meningkatkan kelancaran membaca pada $\mathrm{S}$, penelitian ini hanya dilakukan terhadap satu orang subjek dengan gangguan intelektual taraf ringan yang sudah berusia remaja. Selain itu, keterbatasan dari penelitian ini adalah ketiadaan naskah bacaan yang terstandardisasi. Peneliti hanya menggunakan naskah bacaan yang terdapat pada buku cetak sekolah dasar.

\section{SIMPULAN}

Berdasarkan intervensi yang telah dilakukan terhadap S, dapat disimpulkan bahwa teknik membaca berulang (repeated reading) dapat meningkatkan kelancaran membaca pada anak dengan mild intellectual disability secara efektif, khususnya jika diikuti dengan penggunaan teknikteknik modifikasi perilaku seperti prompts yang diberikan secara bertahap, positive reinforcement, serta positive practice.

Selain itu, wawancara yang dilakukan terhadap ibu partisipan juga menunjukkan bahwa intervensi ini memiliki manfaat lain, yakni meningkatkan motivasi anak untuk membaca. Hasil intervensi juga dapat bertahan ketika anak membaca di luar sesi intervensi.

Hasil penelitian ini menunjukkan bahwa teknik membaca berulang yang juga melibatkan teknik-teknik modifikasi perilaku seperti prompts, reinforcement, serta positive practice dapat meningkatkan kelancaran membaca secara efektif, khususnya pada remaja dengan intellectual disability. Karenanya, intervensi serupa dapat diterapkan di sekolah, tempat terapi, atau di rumah oleh orang tua untuk membantu meningkatkan kelancaran membaca pada anak. Dalam menerapkan intervensi ini, pihak pengajar sebaiknya mencari tahu terlebih dahulu tingkat kemampuan membaca anak serta naskah-naskah bacaan yang sesuai dengan kemampuan anak. Seperti yang dilakukan dalam penelitian ini, intervensi membaca sebaiknya juga melibatkan penggunaan naskah bacaan dan daftar kata.

Untuk memperkuat hasil temuan ini, penelitian serupa sebaiknya dilakukan kembali terhadap partisipan dengan jumlah yang lebih besar. Penelitian serupa juga dapat dilakukan pada partisipan dengan karakteristik lain, misalnya pada anak dengan disleksia atau anak usia prasekolah dengan perkembangan normal yang masih membutuhkan bantuan untuk membaca dengan lancar.

\section{DAFTAR PUSTAKA}

Alnahdi, G. H. (2015). Teaching Reading for Students with Intellectual Disabilities: A Systematic Review. International Education Studies, 8(9). https://doi.org/10.5539/ies.v8n9p79 
American Psychiatric Association. (2013). Diagnostic and statistical manual of mental disoders (5th editio). Washington DC: American Psychiatric Publishing.

Carey, R. G., \& Bucher, B. (1983). Positive practice overcorrection: the effects of duration of positive practice on acquisition and response reduction. Journal of Applied Behavior Analysis, 16(1), 1307865. https://doi.org/10.1901/jaba.1983.16101

Hasbrouck, J., \& Tindal, G. (2017). An Update to Compiled ORF Norms. Behavioral Research and Teaching. Retrieved from http://brt.uoregon.edu

Horst, J. S., Parsons, K. L., \& Bryan, N. M. (2011). Get the story straight: contextual repetition promotes word learning from storybooks. Frontiers in Psychology, 2, 17. https://doi.org/10.3389/fpsyg.2011.00017

Hudson, R. F., Lane, H. B., \& Pullen, P. C. (2005). Reading fluency assessment and instruction: What, why, and how? Reading Teacher, 58(May), 702-714. https://doi.org/10.1598/RT.58.8.1

James, K. P. (2016). Single-subject research method: The needed simplification. British Journal of Education, 4(6), 68-95. Retrieved from www.eajournals.org

Jenkins, J. R., Fuchs, L. S., van den Broek, P., Espin, C., \& Deno, S. L. (2003). Accuracy and Fluency in List and Context Reading of Skilled and RD Groups: Absolute and Relative Performance Levels. Learning Disabilities Research and Practice, 18(4), 237-245. https://doi.org/10.1111/1540-5826.00078

Martin-Chang, S., \& Levesque, K. (2013). Taken out of context: Differential processing in contextual and isolated word reading. Journal of Research in Reading, 36(3), 330-349. https://doi.org/10.1111/j.14679817.2011.01506.x

Martin, G. L., \& Pear, J. (2015). Behavior Modification: What It Is and How To Do It (10th editi). Manitoba: Pearson Education, Inc.

Mirzamani, S. M., Ashoori, M., \& Sereshki, N. A. (2011). The effect of social and token economy reinforcements on academic achievement of students with intellectual disabilities. Iranian Journal of Psychiatry, 6(1), 25-30. Retrieved from http://www.ncbi.nlm.nih.gov/pubmed/22952517

National Reading Panel. (2000). Teaching children to read: An evidence-based assessment of the scientific research literature on reading and its implications for reading instruction. $\mathrm{NIH}$ Publication No. 00-4769, 7, 35. https://doi.org/10.1002/ppul.1950070418

Pertiwi, A. D. (2016). Study deskriptif proses membaca permulaan anak usia dini. Jurnal Pendidikan Anak, 5(1), 757-762.

Pikulski, J. J., \& Chard, D. J. (2005). Fluency: Bridge between decoding and reading comprehension.
The Reading Teacher, 58(6). https://doi.org/10.1598/RT.58.6.2

Serrano, F., \& Defior, S. (2008). Dyslexia speed problems in a transparent orthography. Annals of Dyslexia, 58(1), 81-95. https://doi.org/10.1007/s11881-008-0013-6

Singh, N. N., Singh, J., \& Winton, A. S. W. (1984). Positive Practice Overcorrection of Oral Reading Errors. Behavior Modification, 8(1), 23-37. https://doi.org/10.1177/01454455840081002

Therrien, W. J. (2004). Fluency and comprehension gains as a result of repeated reading A metaanalysis. Remedial and Special Education, 25(4), 252-261. https://doi.org/10.1177/07419325040250040801

van Wingerden, E., Segers, E., van Balkom, H., \& Verhoeven, L. (2017). Foundations of reading comprehension in children with intellectual disabilities. Research in Developmental Disabilities, 60, 211-222. https://doi.org/10.1016/j.ridd.2016.10.015 